\title{
TI in the Institutional Scientific Productivity of Ecuador, Cuba and Colombia
}

\author{
Lisbet Eunice Pérez Anzardo1, Rodolfo González Ortega², Pedro Bruzón Sosa ${ }^{3}$, \\ Catia Ruiz Bosch ${ }^{4}$ \\ ${ }_{1,2,3}$ Teaching Department of the Municipal University Branch Calixto García, University of Holguín, \\ Holguín, Cuba \\ ${ }^{4}$ Teaching Department of Accounting and Finance of University of Holguín, Holguín, Cuba \\ lepereza@uho.edu.cu,rgonzalezo@uho.edu.cu,pbruzons@uho.edu.cu,kruiz@uho.edu.cu
}

\section{Abstract}

Scientific production is one of the indicators of relevance to measure the efficiency in the institutional environment, which implies a development conditioned in all the sectors from the society to world level. In the same way, the technologies of the information (TI) represent a decisive element for their administration which has experienced a constant growth during the last decades similar to the consolidation of the university studies in the different areas of the knowledge and study modalities. The following article makes a reflection on the base of the concepts and tendencies of the scientific investigation and its linking with the technologies of the information. The production of the investigation was characterized in the countries of Ecuador, Cuba and Colombia, as well as the existent relationship among the investment in technologies of the information and the institutional productivity, which was performed with the analysis of bibliometric indicatives. As a result, it was set down the bases for the theoretical-practical deeping of the investigation. Also, it was verified that the investment in IT focused in articles and scientific magazines, contribute to a better knowledge in academic institutions and that the three countries develop policies to motivate this activity, being Colombia the one with more production in the last ten years, as well as the one that has had bigger expense in IT as percentage of the GDP, which is carried out mainly by the government; although the administration of the knowledge has a transcendental impact for the economic and social development of any country.

\section{Keywords}

technologies of the information; scientific production; socioeconomic development

\section{Introduction}

Technologies of the Information (TI) in the models of educational administration have determined a new stage in the socioeconomic development of the countries, and all the characteristics have been transferred from the traditional knowledge to the digital world. Today, it is unavoidable to ignore this dimension like work capital for the importance that it has for the institutional or managerial administration, inside all communicative strategy. The investigation, on the other hand, has experienced a constant growth during the last decades together with the consolidation of the university studies and the development of the technologies of the information.

The importance of the scientific production in the current economy of the knowledge has guided the attention of the academic and managerial world toward the investment in scientific investigation, as an addition of strategic value for the organizations (Mercado- 
SIASAT Journal of Social, Cultural and Political Studies, 7 (1) January 2022, 28-39

ISSN: 2721-7469 (Print), 2721-7450 (Online)

Lisbet Eunice Pérez Anzardo, Rodolfo González Ortega, Pedro Bruzón Sosa, Catia Ruiz Bosch: Tl in the Institutional Scientific Productivity of Ecuador, Cuba and Colombia

https://siasatjournal.com/index.php/siasat

Salgado, 2016). These no longer depend only on the factors: earth, capital and work, but also of the knowledge factor, considered as the fourth component of the production (Cypher, J.M y J Dietz, 2014), which is reflected in the intellectual capital (Martín-deCastro, et al., 2011).

To negotiate that knowledge implies their mensuration, the one that is equipped, therefore, to the financial measures, and it is guided to the process of taking of decisions (Wann-Yih,W et al.,2008; Yi-Chu, H. y J. Yen-Chun, 2010; Rojas, M.I. y Espejo, R.L., 2020) to not achieve competitive advantages alone in function of the tangible resources, but also of intangible ones as the knowledge and capacity to transfer it.

In accordance with the opinion of several authors (Archibald, R.B., and Feldman, D.H., 2011; Bowen, 2013) although the technological advances are generally adopted with the pretext of improving the production mainly in the sector of the services, the academic institutions increase the investment of these without keeping in mind the impact they have in the scientific productivity.

However, there are few studies that characterize the scientific production of the Latin American countries, as well as neither the variables that impact in their behavior. On the base of what has been published with relationship to this area of the knowledge, is defined the contradiction among the lack of scientific productivity in the countries with under development with relationship to the technological investment of the information, which evidences the necessity to investigate their chronological growth; and the behavior of the indicators that impact in it.

The objective that is pursued to give solution to the investigation problem is to contribute to the administration of the knowledge of the thematic study object, and to determine the impact of the institutional scientific productivity starting from the investment in the technology of the information on the base of a bibliometric study; in Ecuador, Cuba and Colombia.

The theoretical novelty of this study resides in the conceptualization, by means of a revision of literature of the concepts of technology of the information in the institutional academic environment and the scientific productivity, besides its relationship for the socioeconomic development. The practical utility is in the use of the database Scopus to characterize the situation and the scientific progress that have had these regions with the purpose of understanding one of the main determinant of the acting of its institutional sector.

\section{Research Methods}

For the development of the investigation it was combined the use of theoretical and empiric investigation methods, among the first ones they stand out that of analysis and synthesis, the abstraction and concretion, the induction and deduction. Inside the empiric methods there are the techniques of summary of the information like interviews and workgroup. It was also used a statistical method to establish statistical correlation of the information obtained by the different scientific methods used during the investigation process, as well as to reveal the tendencies, regularities, and the relationships in the phenomenon study object starting from the information obtained during the investigation process, what allowed to arrive to conclusions. 


\section{Results and Discussion}

\subsection{Technologies of the Information and Their Relationship with Institutional Scientific Productivity in Function of the Socioeconomic Development}

Technologies of the information were developed starting from advances scientists taken place in the computer science's environment and as several authors indicate (Bowen, 2013; Mercado-Salgado, 2016; Rojas, M.I. y Espejo, R.L., 2020; among other) they represent a qualitative step forward of great magnitude in all the environments of the economy and the society, as well as in the change and definition in the ways of how to know and to communicate by means of friendly user's device the signs generated by personal computers and facilities of telecommunications sites, so that it is compressible for another.

There are dissimilar types of TI used in their great majority for the processes and analysis of data that facilitate the resolution of punctual problems, in those that the answer is known and for which all the necessary entrance data exist; the one used for the support of decisions, designed to develop a disposition that takes place as a result of the prosecution reiterated with the equipment participation and investigators that propitiate the mission, starting from the establishment of entrance data and evaluation of the result; that of the expert systems that is based on the use of artificial intelligence that allows the managers to receive expert advice on any problem in which has accumulated knowledge in these systems; among other (What are the technologies of the information. pdf? s.f.)

On the other hand, it is understood as investigation, the systematic activities of search for knowledge that impact in the discipline, topic or area to which it belongs (Barra, 2019). The final results of these are translated mainly in projects, patents and publications of high level that contribute to the territorial and scientific socioeconomic development in diverse areas.

Then; as Flores, E. M., Meléndez, J.M., Mendoza, R.L., (2019) outline, the scientific production is the opinion generated by a group of people with the purpose of giving to know specific general information of a theme; which has as fundamental base other theoretical-practical investigations. In this same order of ideas, one can add that the scientific production refers to the result in form of palpable products as special works of grade (thesis), projects, scientific inventions, among others linked to the academic process. In the same way, favorable instruments for the solution of investigation problems have final presentations as a result in events and publications in magazines of high impact.

Therefore, TI constitute a fundamental element in the correct administration of the scientific productivity that facilitates the work of the investigators inside the superior education, it refers to the support provision and computer services for administrative functions, communication systems, infrastructure, investigation and to improve the teaching-learning process (Lang, 2014); and its attraction has entailed to becomes a main factor in the last decades.

The institutional scientific production is carried out preferably in university by scientists who have as objective to impact in the development, to solve problems or to cover empty spaces of the knowledge, guided to a transformation and socioeconomic renovation and they are generally translated in innovations of practical application, generation of products and services or technological processes in all the countries in general and they represent an indicator subjected to mensuration; which needs of technological capacities for their good acting.

Just as Pérez, C., Gómez, D. and Lara, G., (2018), make it notice the developed countries have bigger technological and investigative capacity related to the third world 
countries. However, most of the empiric studies analyze to depth to the first ones, partly because the developed economies recognize to the science, technology and innovation like fundamental pieces for their strategies of sustained growth, but also partly for the wide statistical wealth which these countries have.

In contrast, the programs of studies of the underdeveloped countries differ of those developed, in spite of the fact that these have a momentous significance in any part, as well as the investment in TI for the transformation in the social, economic and environmental in the managerial and institutional sector.

The technological capacities, at global level, rebound in the cycle of improvement that it bears to the path of the growth and continuous development, which should be supplemented in such way that a new combination of ideas takes place, capacities, abilities, resources, among other factors. According to CEPAL (2007), the invention is before consequence of the process among the factors mentioned; what leads to the study of the thematic for the different investigators in relation to their progression and growth.

On the other hand, Rojas, M.I. y Espejo, R.L., (2020) express that in Latin American countries the university and productive sector manages the science, technology and innovation concepts like simple enunciated theoretical. Also, prevails the absence of political of upgrading the study plans in the university institutions, which leads to the lack of investigations linked with the social and productive environment, which causes that the administrators are only interested by the equipment acquisition more than in the benefit that it represents in the different areas of the knowledge.

For an economy to achieve its splendor it requires of projects and investigations based on the innovation, which is not outstanding if it is not invested in technology of the information, but changes in the technological capacities, managerial and institutional, are generally implemented to improve the quality of the processes instead of the productivity, although TI have helped significantly to the scientific productivity, to eliminate previously inherent geographical barriers to the superior education and to preserve the health in these times of pandemic where crowds are avoided by the infection of the covid-19; since the digital nets have favored the virtual communication and the socialization in their different variants, without keeping in mind the relationship cost-benefit that reports for the development as essential instruments to achieve the peace, to reduce the poverty and to reach the sustainable development.

It is necessary that a use of the projects of $\mathrm{I}+\mathrm{D}$ exists, on the base of the existent relationship between the scientific investigation and the intellectual capital, so that the scientific productivity is developed which brings competition and the socioeconomic development of any country. The victory for the institutions of superior education and the affiliations consists on the capacity to adapt to the fast development of the society in general sense, so that the tactics is to be modernized and to include relative attitudes to values, beliefs, organizational culture, and formation of specialized knowledge applied to the innovation (Zlatea, S. and C. Enache, 2015).

At the present time, the universities have the central character toward the traffic of the so called economy of the knowledge and in the transformation of the processes of economic and social development, on the base of activities like the professional formation so much of pregrade students as graduate degree, the investigation and the linking with the practice to achieve a bigger acting on the part of the government agents, the solution search to problems of each territory, and competitive advantages starting from a gradual improvement not only of the tangible resources but of the intangible ones as the knowledge and the capacity of transferring it; which would not be possible without the technologies of the information. 
On purpose, the scientific production of the Latin American region, that comprises a total of 46 countries, represents a low percentage in relation to the world production. Among the factors that explain this drop contribution one could stand out the faulty institutionalization of the scientific activity, little investment in technologies of the investigation, investigation and development $(\mathrm{I}+\mathrm{D})$, infrequent investment deprived in scientific-technological activities, a low number of professionals dedicated to the investigation, bigger cost of materials and scientific equipment of certain countries that conform this region, among other (Bonilla, C., Merigó, J.M. and Torres- Abad, C., 2015; Chincilla, Z., et tal., 2015; Gerrero, 2017; Moreira, L., et ta., 2020).

As expressed Blanco (2021), to such conditions, which are usually under different forms of scientifically depressed societies, are added the disconnection of scientific tradition and the lack of strategies for the own investigation. Starting from the second half of the century XX, the States has promoted the development of political of science, technology and innovation like fundamental instruments to impel the productivity, the competitiveness and the social and economic development. On that base it has been fundamental the transformation and implementation of action lines under the government administration to favor the intellectual and technological capacities with a view to increase the progress and the population's well-being (Aguilar, 2017).

The investment in technologies of the information is present in scientific institutions and universities, as well as in the managerial sphere; so it is necessary to negotiate from the knowledge and the innovation financial flows with companies and the society on the base of projects; topic that stays in the policies of the underdeveloped countries, in which it is tendency to increase the imports of technologies and the reception of competent professionals.

It represents, also, one of the fundamental variables that characterize the national systems of innovation. In economies very well articulate and developed, the investment in I+D like percentage of the GDP is one of the indispensable indicators to continue developing the economy of the knowledge and, in several, it overcomes 3\% (Núñez, J. and Montalvo, L.F., 2013) A common characteristic of the countries in development is that the technological capacity for investment is generally low, so it is indispensable to take into account the intellectual capacity and especially the imports and technology exports.

It shows that according to Chincilla, Z. et tal., (2015) mentioned by Moreira, L., Morales, J. C., Frizzy, S. and Guerrero, J., (2020) a larger number of articles was observed written in Spanish and of articles published as memoirs of congresses, which could also affect the visibility of the science in countries like Cuba and Ecuador, because, although the scientific production increased in Scopus in the last years, there was a descent of the number of articles in Q1, a decrease of the appointments in each one of the publications and an increase in Spanish language.

These results can be given by the lack of investment in the technologies of the information that rebounds negatively in a bigger quality of the institutional scientific production, as well as for the incipient science that is developing.

The Net of Indicators of Ibero-American and Interamerican Sciences and Technology (RICYT), the Economic Commission for Latin America and the Caribbean (CEPAL), on the base of information of the Organization of the United Nations for the Education, the Science and the Culture (Unesco), make reference to the classification for groups of countries with regard to the GDP for the investment in I+D: the first one corresponds to developed countries, with levels superiors to $2 \%$; in the second group, between $1 \%$ and 2\%, are Spain and Norway, among others; Argentina, Costa Rica and Mexico are inside the third group with an investment of between $0.5 \%$ and $1 \%$; and the 
fourth group, includes countries like Cuba, Chile, Ecuador, Uruguay and Colombia, with value of between $0.2 \%$ and $0.5 \%$, and lastly, with less than $0.2 \%$, countries like Panama and El Salvador (CEPAL, 2016).

For example, according to Núñez, J. and Montalvo, L.F. (2013) in Cuba the tendency is evaluated to the expense in investigation and development (I+D) starting from 1995, it can be affirmed that the average of the percent of the GDP dedicated to I+D it has been of 0,52\%, inferior to the Latin American average. As it is in UNESCO (2011) report on science, in 2010 the global expense in I+D of Cuba went back and it was below the regional average.

In spite of the economic-financial embargo imposed to Cuba for more than 60 years, the government's politics has been to preserve and to support the sector of I+D which has propitiated that the institutions and universities continue working with the limited resources with which they count, so that it is guaranteed the wage at least to the personnel dedicated to the investigation and to cover other expenses in national currency to expense of the flight of intellectual capital since exists the impossibility of assisting the necessities of materials, specialized inputs and teams that need the institutes of $\mathrm{I}+\mathrm{D}$, the universities and companies.

In the same way, Ecuador has been one of the countries where the scientific production of Latin America has increased, in spite of its little tradition in this field. The government, by means of the public institutions of superior education (IES), has implemented in this system educational policies for the development of the science in the country (Álvarez, P. and Pérez, M., 2016), as the project Prometeo that was implemented as initiative promoted by the National Secretary of Superior Education, Science and Technology (SENESCYT), to stimulate the investigation in universities that have an advantageous position, starting from the international collaboration of scientific with grateful trajectory to develop projects that contribute in high-priority areas of the knowledge, together with the welcome institution (SENESCYT, 2015; Van Hoof, 2015).

Castillo, J.A. and Powell, M.A. (2019) demonstrated that $80 \%$ of the scientific articles published in Scopus by Ecuadorian authors were carried out in collaboration with investigators of other countries, demonstrating the benefit of receiving international help.

The scientific production of the universities and institutions of this country is below the 100 articles in the last years in magazines of high impact, of the database of Scopus, for example; and this way it has not been able to place inside Scimago Institutions Ranking that is a categorization that registers the 1000 better scientific affiliations at world level (Moreira, L., Morales, J. C., Frizzy, S. and Guerrero, J., 2020).

Of equal it forms, in Colombia at the end of the $\mathrm{XX}$ century, the investigation concentrated on five institutional sectors: universities, public investigation institutes, private investigation centers, companies of the sector of the services and production, as well as national or international organisms belonging to the country. The financial resources for the investigation and the technological development came from three main channels: resources of the national budget assigned to institutions of investigation of the public sector and the universities; investments of the private sector through the budget of private centers, parataxes funds or expenses of investigation of the sector and resources channeled through National Programs of Science and Technology, of the national budget or of external credit through Colciencias (Leamsson, J. and Chiappe, M., 1999).

To promote the growth of TI and the investigation works, Colombia adopted some policies during the last 20 years in this field by means of Colciencias. It financed and created scientific groups, besides scholarships of masters and doctorates in foreign countries, as well as cooperation and interinstitutional agreements with other countries. 
From the state-run thing, the investment dedicated to the investigation had arrived to $1 \%$ of the GDP for the year 2010.

The impossibility to favor the administration of the knowledge is in agreement with the insufficient investment in technology, which is reaffirmed by Wassermann (2019) when he expresses that the nonexistence of a planning of investigations to medium and long term and the decrease of the financing granted by Colciencias has been indicative that have an effect in the institutional scientific production of the country; as well as the little investment in CTI like percentage of the GDP.

In accordance with the report of the biggest database of summaries and literature appointments revised anonymously and available in webs of quality, SCimago Journal Ranking (SJR) that is a classification of magazines elaborated starting from the electronic database of SciVerse Scopus, and other carried out studies; it could diagnose himself in a general way the institutional scientific productivity of Ecuador, Cuba and Colombia from the 2010 until the present time. There were established selections approaches like: published documents, thematic related with TI, affiliations, and investigation areas.

The results were presented with use of descriptive statistic in form of graphics and charts.

Colombia was the country with bigger scientific productivity in this period with a total of 1951 documents, followed by Ecuador with 1158 and Cuba with 357 just as it is shown in the Figure 1.

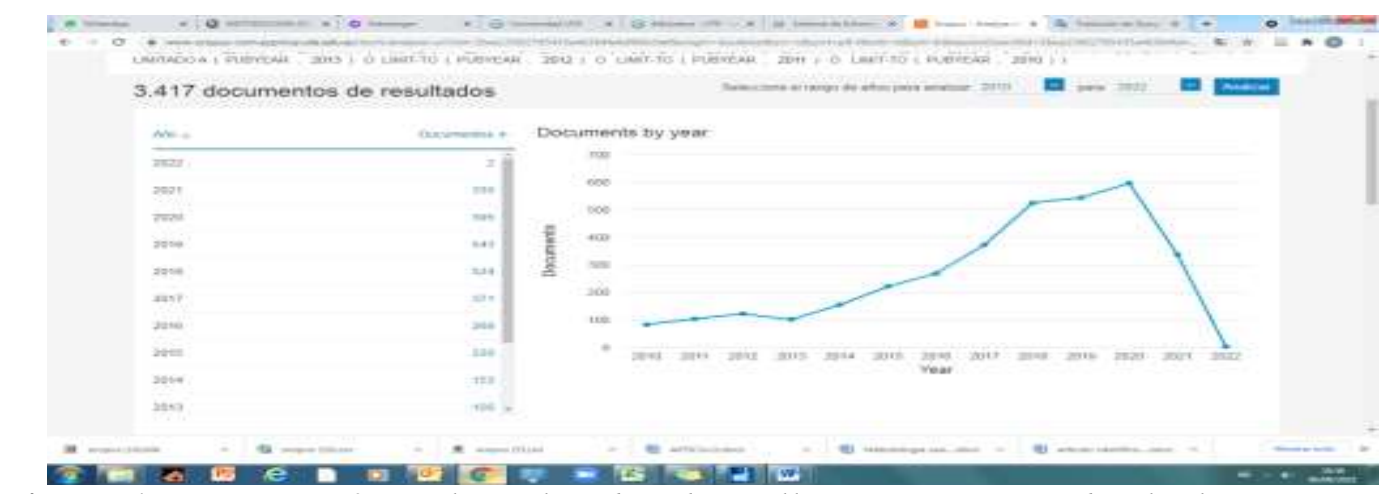

Figure 1. Quantity of articles related with intelligent systems and calculation Source: electronic database of SciVerse Scopus

Also, the year 2020 as the one with the most scientific productivity, just as reproduces the Figure 2, and also in thematic related with advances in intelligent systems and calculation.

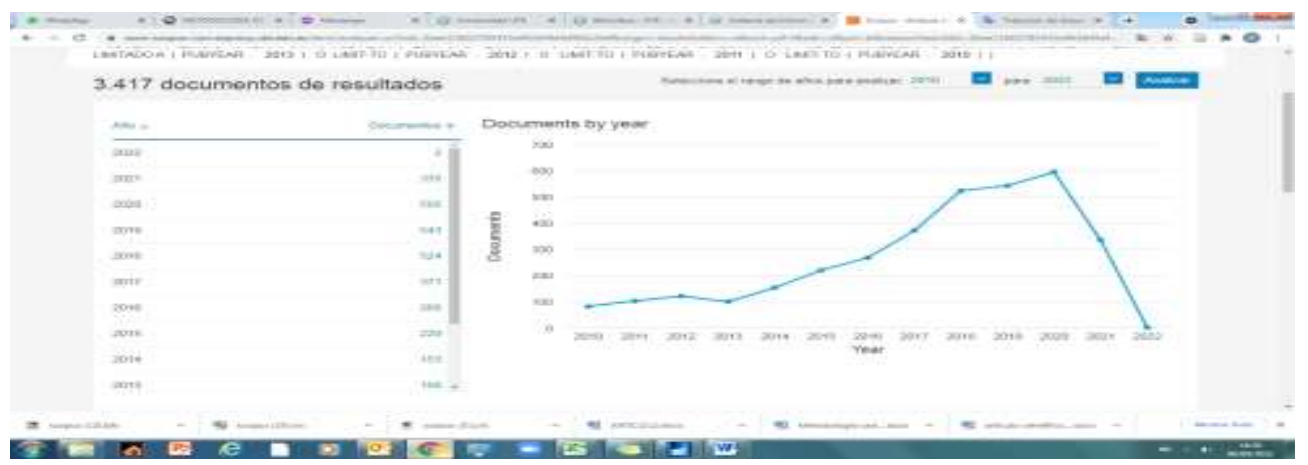

Figure 2. Quantity of articles related with intelligent systems and calculation Source: electronic database of SciVerse Scopus 
The most outstanding affiliations were the University of the Armed Forces ESPE, the Popular Technical University of Loja, the University of The Andes in Colombia, University of the Cauda, National University of Colombia, among others that are shown in Figure 3.

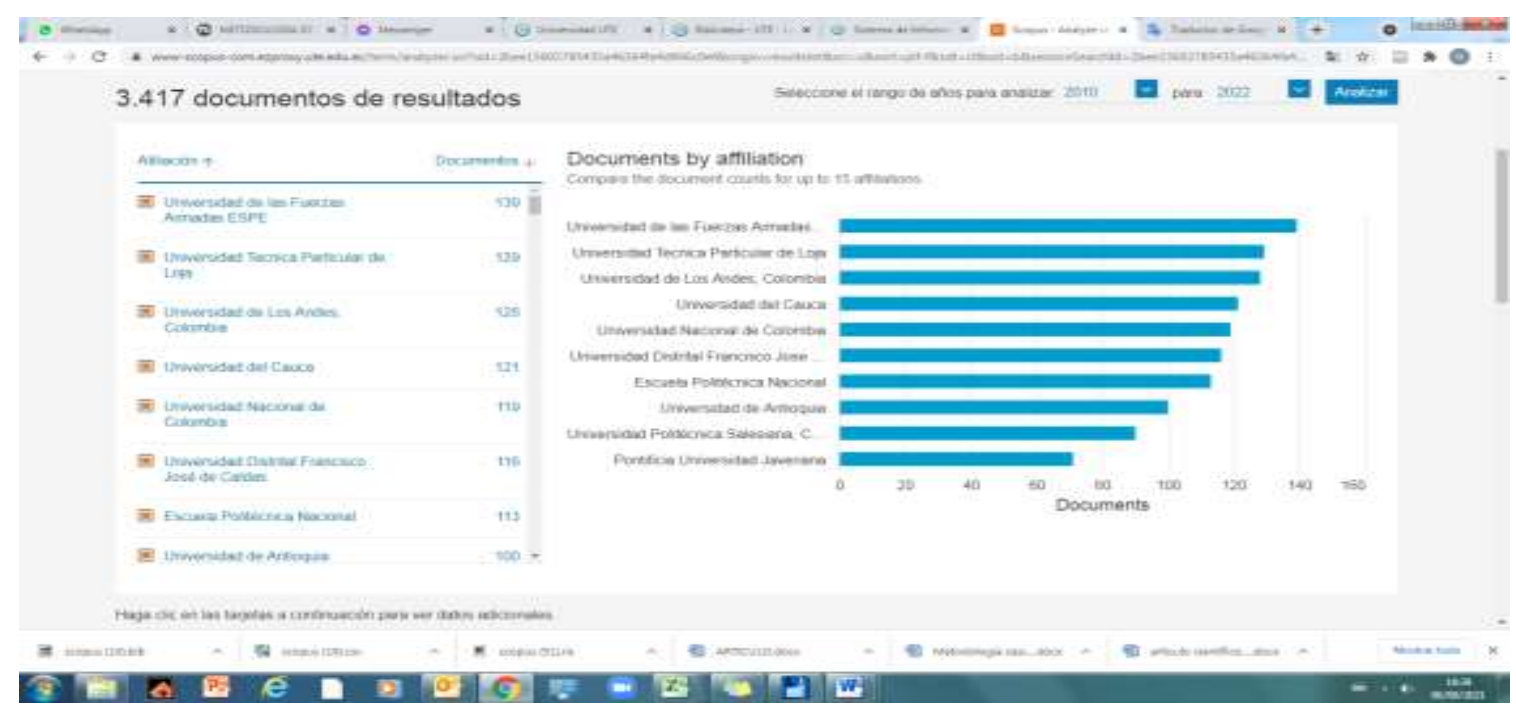

Figure 3. Most outstanding Affiliations in the scientific production Source: electronic database of SciVerse Scopus.

Also, in Figure 4 are shown that the most outstanding thematic areas were sciences of the calculation with 1703 documents; business, administration and accounting with 321 ; sciences of the decision with 296; among others.

Documents by subject area

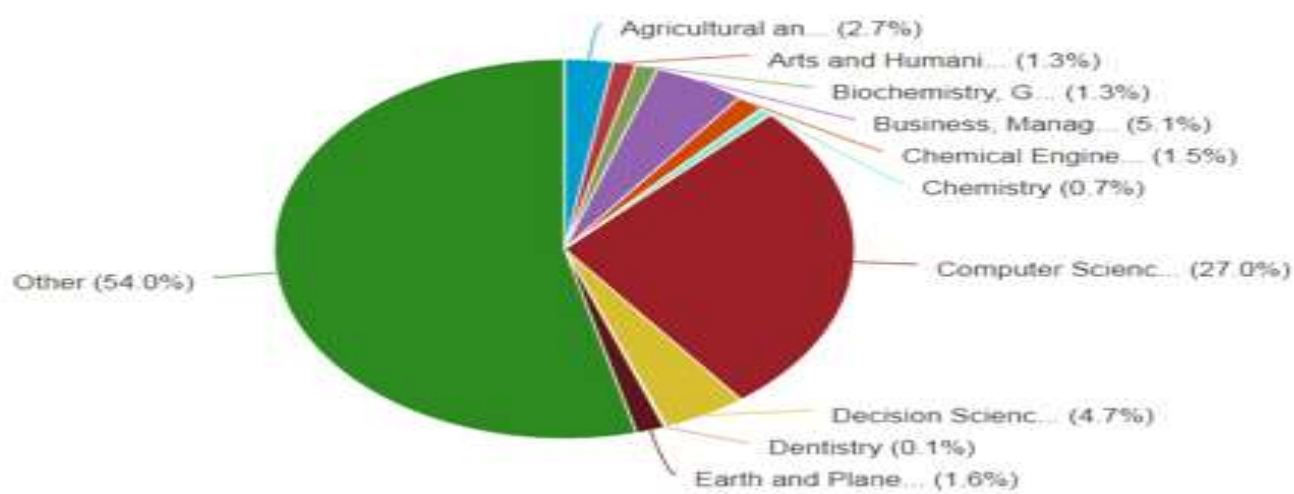

Figure 4. Most outstanding thematic Areas

Source: electronic database of SciVerse Scopus.

Chart 1 illustrates the behavior of the expense carried out by the three reference countries during the last six years in CTI. The amounts are given in MMP of USD, according to the date exchange rate September 24, 2021. Seemingly, it is contradictory with relationship to the scientific productivity shown previously; although it is already known that Ecuador, Cuba and Colombia are in the fourth group of countries which have a minimum investment in CTI regarding their GDP (CEPAL, 2016). Also, it is important to 
point out that this balance associated includes other expenses linked to the activity like the workers' wages.

Ecuador and Colombia are those with the smaller incidence in this field, caused mainly by the importation of investigator, material and technology as well as the investment in Cuba is carried out mainly by the government.

Cuba, on the other hand, is the country with the biggest expense in CTI, due mainly to the cost associated to the purchase of materials and scientific equipment because by the USA embargo and other factors that impact in its administration. Although there are investigations with huge knowledge and financing is dedicated to the projects of I+D; the investment lack and the cost of the technology has shown a negative incidence in the scientific productivity.

Table 1. Spend in CTI during the period 2015-2020

UM: MMP in USD

\begin{tabular}{|l|l|r|l|l|r|r|r|r|}
\hline Country & Year & $\begin{array}{c}\text { Expense } \\
\text { in CTI }\end{array}$ & Country & Year & $\begin{array}{c}\text { Expense } \\
\text { in CTI }\end{array}$ & Country & Year & $\begin{array}{c}\text { Expense } \\
\text { in CTI }\end{array}$ \\
\hline Ecuador & 2015 & 38,3 & Cuba & 2015 & 52,9 & Colombia & 2015 & 11,9 \\
\hline Ecuador & 2016 & 32,1 & Cuba & 2016 & 66,5 & Colombia & 2016 & 12,8 \\
\hline Ecuador & 2017 & 16,1 & Cuba & 2017 & 59,1 & Colombia & 2017 & 12,9 \\
\hline Ecuador & 2018 & 19,0 & Cuba & 2018 & 75,7 & Colombia & 2018 & 12,3 \\
\hline Ecuador & 2019 & 13,3 & Cuba & 2019 & 59,4 & Colombia & 2019 & 13,4 \\
\hline Ecuador & 2020 & 14,0 & Cuba & 2020 & 82,4 & Colombia & 2020 & 14,0 \\
\hline
\end{tabular}

Sources: ONEI 2020 and 2021

CITMA.2019-2020

Official pages of the Ministry of Telecommunications of Ecuador. 2015-2020

Official pages of the Ministry of Computer Technology and the Communications of Colombia. 2015-2020

Stiglitz (2012) mentioned by Pérez, C., Gómez, D. and Lara, G., (2018), notices that investing more in our society (education, technology and infrastructure) and to provide more security to the citizens will generate a more efficient and more enterprising economy; safer, bound to what is wanted to be in the immediate future which offers possibilities to all the sectors of the society; where the existent diversification is recognized in Latin America and one keeps in mind the advantages that it offers to have a wide technological capacity in the social context.

In such a sense, it is necessary to favor inside the universities and academic institutions an investigative culture based on an impact so much economic as social, and in a same way to generate competitiveness in the educational ones to favor the development starting from projects centered in the solution of the social problems.

In this sense, the university should be conceived as a social project, where applicable knowledge are generated to the reality of the territories and these centers become community leaders so much in the student formation as transformers of the society; although the scientific productivity is in risk due to factors related to the lack of economic and technological resources; and also for the lack of the managerial and institutional agents' administration.

In consequence, the universities should promote agreements with the different entities of the State, National Fund of Science, Technology and Innovation (FONACIT), public or private companies and all those institutions that facilitate the investigative activity, so that agreements that facilitate the financing to implement national as 
international projects which open a route to the scientific investigation, the participation in events and the publications. To deny the support that science requires means a delay and stagnation for any country, making a nation with technological dependence subject to the discoveries of foreign countries (Pérez, C., Gómez, D. and Lara, G., 2018).

To know the institutional scientific production in the different areas of the knowledge and to study the investment in IT, as well as the capacity to adopt, to adapt and to improve the new technologies, transcends beyond the direct benefits that are perceived in form of economic growth, since it involves elements like the teaching-learning process which has to do with the quality of the environment of the nations and with the innovation to get the sustainable development. For such a reason it is necessary to mitigate the negative external structures that are generated on the base of economic, social and environmental benefits; which evidences a challenge to measure and to evaluate.

\section{Conclusion}

The analysis of the concurrent terms allowed to establish approaches common with the consulted authors, and on the base of the contribution so much theoretical as practice it is demonstrated that the institutional scientific productivity has a narrow relationship with the investment in IT to achieve bigger innovation levels and development; so it is due to establish politics to motivate their administration so that it provides a sustainable socioeconomic growth in any part of the world.

The studies related with the characterization and comparison of the scientific activity in the underdeveloped countries are insufficient although it gives a vision of their acting and allows to take strategies to favor their situation, starting from a diagnosis that shows the indicators that impact negatively, knowingly of their narrow relationship with the development of the society so much in the academic mechanism as the productive one.

The scientific productivity of Ecuador, Cuba and Colombia has had a light growth in the last decade due to politics of collaboration among the three countries mainly, although persist deficiencies that limit its development related with the little investment in technologies of the information, the lack of professionals linked at the investigative activity and the cost of the equipment.

With the realization of this study it gets ready the way for future investigations on this topic and it is a contribution to the advance in the knowledge of this study field.

\section{References}

¿Qué son las tecnologías de la información. pdf? (s.f.). Obtenido de http://www.ceupe.com/images/easyblog_articles/2374/tecnologas-de-lainformaci_2020051 9-1 4061 7_1.jpg

Aguilar, M. (enero-abril de 2017). Indicadores de ciencia, tecnología e innovación y su impacto en el desarrollo de políticas públicas. TELOS. Revista interdisciplinaria en Ciencias Sociales, 19(1), 119-146. Obtenido de http://ojs.urbe.edu/index.php/telos/article/view/788/715

Álvarez, P. y Pérez, M. (sep. de 2016). Políticas científica s públicas en Latinoamérica: el caso de Ecuador y Colombia. El profesional de la información, 25(5), 758-766. Obtenido de https://doi.org/10.3145/epi.2016.sep.06

Archibald, R.B., y Feldman, D.H. (2011). Why does college cost so much? New York, NY: Oxford University Press. 
Barra, A. M. (junio de 2019). La importancia de la productividad científica en la acreditación institucional de universidades chilenas. La serena, 12(3). Obtenido de http://dx.doi.org/10.4067/S0718-50062019000300101

Blanco, C. (ene-jun. de 2021). Investigación científica en Venezuela y Colombia contemporáneas: breve síntesis. UH(291). Obtenido de http://orcid.org/0000-0002-01 75-247X.Scielo

Bonilla, C., Merigó, J.M. y Torres-Abad, C. (2015). Economics in Latin America: a bibliometric analysis. Scientometrics, 105(2), 1239-1252. Obtenido de https://doi.org/10.1007/s11192-015-1747-7

Bowen, W. (2013). Higher education in the digital age. Princeton, NJ: Princeton University Press.

Castillo, J.A. y Powell, M.A. (2019). Análisis de la producción científica del Ecuador e impacto de la colaboración internacional en el período 2006-2015. Revista Española de Documentación Científica 42:225. Obtenido de https://doi.org/10.3989/redc.2019.1.1567

CEPAL. (2007). Indicadores de capacidades tecnológicas en América Latina, Serie Estudios y Perspectivas, México, Naciones Unidas. Obtenido de http://www.cepal.org/es/publicaciones/5014-indicadores-de-capacidadestecnológicas-en-america-latina

CEPAL. (2016). Ciencia tecnología e innovación en la economía digital: la situación de América Latina y el Caribe. Segunda reunión Conferencia de Ciencia, Innovación y Tecnologías de la Información y las Comunicaciones de la CEPAL, desarrollada el 12 y 13 de Septiembre. San José. Costa Rica. Obtenido de https://repositorio.cepal.org/bitstream/handle/11362/40530/3/S1600833_es.pdf

Chincilla, Z., Arencibia, R., De Moya, F. y Corera, E. (2015). Somes patterns of Cuban scientific publication in Scopus: the current situation and challenges. Scientometrics, 103, 779-794. Obtenido de https://doi.org/10.1007/s11192-015-1568-8

CITMA (2020) Prontuario 2019-2020 Actividad rectora. Ministerio de Ciencia, Tecnología y MA. Obtenido de http://prector-19-20.pdf

Cypher, J.M y J Dietz. (2014). The process of economic development. 3ra Ed. ISBN 780415771030-9780415771047-9780203895061.

Flores, E. M., Meléndez, J.M., Mendoza, R.L. (2019). Producción científica como medio para la transformación social desde las universidades. Revista Scientific, 4(14) (Ministerio de Telecomunicaciones de Ecuador , 2015) (Ministerio de Telecomunicaciones de Ecuador , 2015), 62-84.

Franco, M., Ramos, L. y Hernández, Y. (2016). Combinación de datos de corte tranversal y de series temporales. Universidad de Oriente.

Gerrero, J. (2017). Producción científica latinoamericana indexada en Scopus en el área de las ciencias agropecuarias: análisis del período 1996-2016. Idesia, 35(4), 27-33. Obtenido de https://scielo.conicyt.cl/pdf/idesia/v35n4/0718-3429-idesia-35-040027.pdf

Lang, L. (2014). 2013 CDS executive summary report. Louisville, CO: EDUCAUSE Center for analysis and research.

Leamsson, J. y Chiappe, M. (1999). La investigación universitaria en América Latina. IESALC/UNESCO.

Martín-de-Castro, G. M.-V.-S.-L. (2011). An intellectual capital-based view of the firm: origins and nature. Journal of Business Ethics 98 (4), 649-662. doi:10.1007/s10551010-0644-5 
Mercado-Salgado, P. (2016). Validez inicial de una escala de medición del capital intelectual en universidades. Universitas Psychologica, 15(2), 109-119. doi:org/10.11144/Javeriana.upsy15-2.viem

Ministerio de Tecnología Informática y las Comunicaciones de Colombia (2015-2020). Obtenido de http://Col2015.pdf; http://Col2016.pdf; http://Col2017.pdf; http://Col2018.pdf; http://Col2019.pdf; http://Col2020.pdf

Ministerio de Telecomunicaciones de Ecuador (2015-2020). Obtenido de http://ecua2015.pdf; http://ecua2016.pdf; http://ecua2017.pdf; http://ecua2018.pdf; http://ecua2019.pdf; http://ecua2020.pdf

Moreira, L., Morales, J. C., Crespo, S. y Guerrero, J. (ene./mar. de 2020). Caracterización de la producción científica de Ecuador en el período 2007-2017 en Scopus. Investigación bibliotecológica. Obtenido de https://doi.org/10.22201/iibi.24488321xe.2020.82.58082

Núñez, J. y Montalvo, L.F. (2013). La política de ciencia, tecnología e innovación en la actualización del modelo económico cubano: evaluación y propuestas. Economía y Desarrollo.

ONEI (2020) Anuario estadístico de Cuba,2020. Ciencia y Tecnología. Edición 2021. Obtenido de http:// 16_ciencia_y_tecnologia_2020_0.pdf.

ONEI (2019) Anuario estadístico de Cuba,2019. Ciencia y Tecnología. Edición 2020. Obtenido de http:// 16_ciencia_y_tecnologia_2019_0.pdf

Peña, N., Pérez-Anzardo, L.E., Bruzón, P. y Pérez-Campdesuñer, R. (2018). Bibliometric analysis of scientific production on tourism and tourism product. Education Journal. Obtenido de http://www.sciencepublishinggroup.com/j/edu

Rojas, M.I. y Espejo, R.L. (Febrero de 2020). La inversión en investigación científica como medida del capital intelectual en las instituciones de educación superior. La serena, 31(1). Obtenido de http://dx.doi.org/10.4067/S0718-07642020000100079

SENESCYT. (2015). Proyecto PROMETEO. Obtenido de http://prometeo.educacionsuperior.gob.ec/

Stiglitz, J. (2012). The price of inequality: how today's divided society endangers our future, W.W. Norton.

Van Hoof, H. (2015). Eduador's efforts to raise its research profile: the prometeo program case study. Journal of Hispanic Higher Education, 14(1), 56-68. Obtenido de http://doi.rog/10.1177/1538192714543664

Wann-Yih,W., C.Man-Ling y C.Chih-Wei. (2008). Promoting innovation through the accumulation of intellectual capital.Social capital, and entrepreneurial orientation. $\mathrm{R}$ and D Management.38(3). 265-227. doi:org/10.1111/1467-9914.00120-i1

Wassermann, M. (19 de abril de 2019). El nivel de inversión en ciencia en Colombia es bajísimo. El Heraldo. Obtenido de https://www.elheraldo.co/ciencia/el-nivel-deinversión-en-ciencia-en-colombia-es-bajísimo-moises-wasserman-625700

Yi-Chu, H. y J. Yen-Chun. (2010). Intellectual capital and knwoledge productivity: the Taiwan biotech industry. Management decision, 48 (4) 580-599. doi:org/10.1108/002517410110413364

Zlatea, S. y C. Enache. (2015). The interdependence between human capital and organizational performance in higher education. Procedia - Social and Behavioral Sciences, 180(5), 136-143. doi:org/10.1016/j.sbspro.2015.02.096 